University of Pennsylvania Carey Law School

Penn Law: Legal Scholarship Repository

Faculty Scholarship at Penn Law

7-1-2005

\title{
Why Defer to Managers? A Strong-Form Efficiency Model
}

Richard E. Kihlstrom

The Wharton School, University of Pennsylvania

Michael L. Wachter

University of Pennsylvania Carey Law School

Follow this and additional works at: https://scholarship.law.upenn.edu/faculty_scholarship

Part of the Business Organizations Law Commons, Corporate Finance Commons, and the Law and Economics Commons

\section{Repository Citation}

Kihlstrom, Richard E. and Wachter, Michael L., "Why Defer to Managers? A Strong-Form Efficiency Model" (2005). Faculty Scholarship at Penn Law. 70.

https://scholarship.law.upenn.edu/faculty_scholarship/70

This Article is brought to you for free and open access by Penn Law: Legal Scholarship Repository. It has been accepted for inclusion in Faculty Scholarship at Penn Law by an authorized administrator of Penn Law: Legal Scholarship Repository. For more information, please contact PennlawIR@law.upenn.edu. 


\title{
Preliminary: Not to be Quoted without Permission from the Authors
}

\author{
Why Defer to Managers? A Strong-Form Efficiency Model
}

by

\author{
Richard E. Kihlstrom \\ The Wharton School \\ and \\ Michael L. Wachter \\ The Law School \\ University of Pennsylvania ${ }^{\dagger}$
}

July 2005

\begin{abstract}
We compare the efficiency with which management discretion and shareholder choice regulate hostile tender offers. This is the first paper in a long running debate that rigorously compares these legal rules to analyze both the critical informational assumptions and the interplay of those assumptions with principles of financial market efficiency. A critical innovation of our model is its focus on an informed management's choice among alternative corporate policies under the protection of the business judgment rule, but where agency costs exist. We assume that corporate assets and reinvestment opportunities are efficiently priced by financial markets, but that markets never learn the value of foregone investments. In this case, shareholder choice may create an agency problem whereby managers forego positive net present value investments that increase the risk of a hostile bid. We are able to determine analytic conditions under which the expected cost of this agency problem exceeds that of the standard agency problem usually identified with management discretion.
\end{abstract}

In this paper we explore again the efficient legal rule to govern hostile tender offers. ${ }^{1}$ Most of our discussion involves the choice between two stylized legal regimesmanagement discretion, a position associated with that of the Delaware courts, ${ }^{2}$ and shareholder choice, a position long favored by most legal academic commentators. ${ }^{3}$ The question posed by the academic commentators, in particular, by Ronald Gilson is whether the Delaware rule has a coherent justification for favoring management discretion (Gilson 2001). ${ }^{4}$

More recently, commentators have come to the defense of management discretion. Michael Wachter (2003), in answering the question posed by Ronald Gilson (2001) argued that management discretion is superior to shareholder choice if financial markets have transitory departures from efficiency and informed managers react to a shareholder choice regime by managing to the market. In the example offered by 
Wachter (2003) informed managers adopt corporate policies that the managers believe to be inferior but are favored by the market. In a Penn Law symposium on Corporate Control Transactions, Richard Kihlstrom and Wachter (2003) modeled the managing to the market phenomenon, showing under what conditions management discretion was superior to shareholder choice. We argue that under shareholder choice managers have an incentive to adopt takeover defenses prior to the emergence of a takeover bid and that these are effective defenses that courts cannot regulate because they are protected by the presumption of the business judgment rule and are not subject to Unocal/Unitrin scrutiny.

Two other papers presented at that symposium offered complementary justifications of management discretion (Kahan and Rock, 2003; Arlen and Talley, 2003). ${ }^{5}$ A major question that remained unanswered after the symposium was the extent to which a conclusion favoring shareholder choice rests on assumptions about financial market inefficiencies.

In this paper we assume strong-form efficiency as that term is generally understood. Specifically, we assume that investors know the present value of the free cash flow generated by the firm's existing assets and the reinvestment returns generated by those future free cash flows. ${ }^{6}$ We assume strong-form efficiency because that assumption is the most favorable to the shareholder choice position. ${ }^{7}$ The question answered in this paper is the extent to which critiques of shareholder choice ultimately rest on failures in financial market efficiency.

Our answer is that strong-form efficiency is not sufficient to provide unambiguous support for a shareholder choice legal regime. The reason, as we discuss in earlier papers, is that managers have the ability to choose among corporate policies in a manner that reduces the probability of a takeover in ways that are undetected or even sanctioned by the financial markets. We focus on corporate policy because the choice among corporate policy opportunities is the central function of the managers and the decision that is most likely to have a significant effect on the market value of the corporation.

Modeling corporate policy as the cornerstone in the analysis is also useful because the Delaware courts' most persistent argument in favor of their takeover law doctrine is the need to protect the ability of managers to adopt policies that maximize the value of the corporation and the shareholders' interest. Although a management discretion regime may be favored for reasons unconnected with the Delaware courts' reasoning, we show that, in fact, the Delaware courts' position is consistent with the argument that we develop.

While financial markets may become strong-form efficient when pricing the value of the corporation based on its current corporate policies and assets, markets are not as well informed as are managers about new corporate policy opportunities. In particular, if corporate policy opportunities are not adopted, markets have no way of knowing what the firm's value would have been had the policy been adopted. Thus managers can, if it is in their interest, forgo policies that they know to be value enhancing. Such a maneuver 
might be in the managers' interest if the adoption of the policies would increase the chance of a hostile tender offer. The maneuver is not self-defeating because it does not get built into the market price. More formally, there are informational asymmetries inherent in the fact that managers are more informed about how to best conduct the business and affairs of the incorporation, and not all of this information becomes publicly disclosed.

On the other hand, if the financial markets could incorporate the possibility of future corporate policy opportunities, they could discount the firm's value to reflect the costs of this agency problem. However, to assume that the market knows the value of all corporate policy options that might be forgone in the future and can incorporate this into share prices is to assume a kind of hyper-efficiency that goes well beyond strong-form efficiency. Financial markets might be hyper-efficient in the way we use the term, but there is no evidence that this is so.

As a consequence, in periods prior to the emergence of a hostile bid, when management decisions are protected by the presumption of the business judgment rule, managers could adopt those corporate policies that best provide them with protection against takeovers instead of adopting the corporate policies that maximize the value of the corporation. We argue that whereas managers may act in this way in a shareholder choice legal regime, they have no apparent reason to act in this manner in a management discretion legal regime. This is an agency cost of a shareholder choice regime that we discussed in our earlier paper and that had not been incorporated into earlier models of shareholder choice.

In this paper, by explicitly modeling the agency cost problem and allowing for synergistic bidders, we can provide an explicit representation of when shareholder choice or management discretion is the efficient rule. We assume that management discretion allows for higher agency costs than does shareholder choice, and that the private benefits under management discretion are the maximum benefits that managers can extract without violating their duty of loyalty. The efficiency tradeoff then turns on whether the loss associated with a less than optimal corporate policy is larger or smaller than the higher agency costs associated with management discretion.

We also extend our analysis to take account of an alternative legal rule that can fall between shareholder choice and complete management discretion. This rule, for example, would capture a regime that both facilitated a bidder's ability to wage a proxy contest for control of the firm and provided heightened scrutiny that restricted managers' ability to alter the voting rules in their favor. We show that under certain conditions, such a regime is unambiguously inferior to either management discretion or shareholder choice because it may increase the cost of a bid while not encouraging managers to maximize the value of the firm.

\section{Incomplete Information and the Choice of a Legal Regime}


In this section we focus on the informational issues that help determine the efficient legal rule for governing hostile tender offers. Given the complexity of the issues and their importance to the workings of any model of takeover defenses we describe them in some detail.

Informational issues are at the core of any analysis of the allocation of power between shareholders and directors. It is generally agreed that managers know more than investors as to how to conduct the business and affairs of the corporation; a principle that provides the basis for the business judgment rule presumption that protects directors' ability to make largely unchallengeable business judgments. ${ }^{8}$ No one contests the conclusion that the choice among corporate policies has to be made by managers and not by shareholders. It is also generally agreed that the separation of ownership and control means that managers may act for their own private benefit rather than as faithful fiduciaries and thus not maximize the value of the corporation. This creates the classic corporate law dilemma: if managers are given unconstrained authority they may act in their own interest, yet if their authority is too constrained they may be unable to adopt the corporate policies that they know are best for the corporation. ${ }^{9}$

It is often argued that this problem becomes unimportant if capital markets are efficient in the strong sense. When markets are strong-form efficient, then the financial market and hence shareholders know as much about the value of the firm as do managers. However, the evidence to support this assumption is scanty, with the empirical evidence providing better support for semi-strong-form efficiency. A convenient and plausible assumption is that capital markets become strong-form efficient in the midst of the disclosure-rich environment of takeover battles. ${ }^{10}$ Because a task of this paper is to explore the importance of strong-form efficiency in the debate over the appropriate takeover defense policy, we adopt the assumption that financial markets are always strong-form efficient. ${ }^{11}$ Specifically, investors and potential bidders learn the correct value of the corporation - that is, the present value of the free cash flow generated by the firm's current assets and the reinvestment returns generated by those future free cash flows.

In carefully discussing the informational issues at stake, we note an important corollary assumption; namely that the market and potential bidders also know the value of the private benefits received by the managers. The existence of private benefits makes the firm attractive as a takeover candidate since those benefits can be captured by the bidder who succeeds in buying the firm.

The assumption that the private benefits of the managers are known to the market seems plausible. Elements of those private benefits are publicly disclosed when the highest-level executives reveal their compensation, both the fixed salary and the incentive components, in Securities and Exchange Act filings. ${ }^{12}$ In addition, corporate decisions that constitute interested transactions can be challenged by shareholders and can become publicly known through the mechanism of a shareholder informational suit followed by a shareholder derivative suit. Since the information about private benefits is disclosed, it is incorporated into market prices even with semi-strong efficiency. Strong-form efficiency 
goes further and includes in market prices the value of private benefits that are not disclosed. In strong-form efficiency, all of the private benefits - whether publicly disclosed or not disclosed but otherwise discovered by investors-become priced into the value of the firm's shares.

The important distinction that we make is the following. On the one hand, the market accurately values all of the investments actually made by the firm and all of the corporate policies implemented by management. It also prices in the private benefits extracted by management. On the other hand, the market is unable to price in the value of those corporate policy opportunities that are considered but rejected by the managers. Our key assumption, then, is that while markets are strong-form efficient when pricing the actual value of the corporation, they do not price in the effects on corporate value that occur when managers forgo certain corporate policy opportunities. It is unlikely that information on the value of forgone corporate policy opportunities will ever become known to the financial market. While federal disclosure requirements apply effectively to the value of the current assets and polices, there is no requirement that the corporation disclose policy opportunities that the managers decide to forgo. In addition, information on the value of forgone corporate policy opportunities could not be easily ferreted out using shareholder informational rights under state law.

As we have already noted, we would be moving well beyond strong form efficiency to a kind of hyper-efficiency if we were to assume that the values of all corporate policy options were incorporated into share prices-whether those policies were adopted or not. Shareholders might well be aware that the agency problem discussed here exists and that a corporate policy opportunity has arisen and has been rejected by managers who knew its true value. But, without hyper-efficiency of the kind we rule out, outside investors can never know if a particular policy was rejected because it was not a positive NPV opportunity or because managers were acting opportunistically.

A related issue is whether shareholders could anticipate the future occurrence of the agency problem we have identified and could estimate its future cost. When investors are aware of the agency problem, it is natural to suppose that they would, to the extent possible, attempt to estimate the expected cost of its future impact on the firm's value. If that were indeed possible, the market would reduce the value of the firm by this amount. However, it is difficult to imagine that markets will, in fact, know enough about the probability of occurrence and the value of possible future policy opportunities to be able make this calculation in any way that is not effectively arbitrary. These are among the many unforeseen future contingencies that impact the firm and determine its value. The idea that not all future contingencies can be envisioned and prepared for is the basis for seminal contributions of Williamson (1979) and Grossman and Hart (1986). ${ }^{13}$

Similarly, if financial markets were hyper-efficient and the informational costs were low, the agency problem we discuss could be resolved by contract. That would be possible if shareholders eventually learn the value of all corporate opportunities, including those that were forgone by managers. Shareholders would then know when managers had acted in their own interest by failing to implement a positive NPV 
corporate policy and, when that happened, managers could be sanctioned. Managers, however, would be deterred from engaging in such behavior if they knew that it would ultimately be punished by shareholders. It seems highly implausible, however, that the market could eventually learn the value of corporate policies that are never implemented.

It might be thought that the agency problem introduced by shareholder choice can be ameliorated by the use of golden parachutes and other severance payments. These compensate managers when they lose their jobs in the context of a takeover. We will argue that golden parachutes are ineffective devices for preventing the problem we describe and that they serve to enhance the value of management discretion relative to shareholder choice. Furthermore, even if golden parachutes were effective they would over-compensate managers for the problem we identify because they make a payout whenever the managers lose their job in a merger. They are not conditioned on the specific problem - managers rejecting corporate policy opportunities that are profitable because it threatens their job tenure. Since the golden parachutes are not so conditioned and make payouts too often, they are an inefficient mechanism for controlling for the agency cost problem. We return to this issue below in the context of our formal model.

At the end of the day, managers remain imperfectly monitored and strong-form efficiency, as that term is generally understood, does not resolve the problems created by the need to give managers the ability to choose among the corporate policy opportunities available to the firm. Ultimately there is no clear resolution of the classic dilemma. The choice between management discretion and shareholder choice involves difficult tradeoffs.

\section{The Model}

\subsection{Introductory Comments}

For the purpose of the current discussion, we follow our earlier paper and identify a firm's corporate policy with the investment decisions that accompany the implementation of that policy. ${ }^{14}$ In particular, we consider a situation in which the managers have an opportunity to implement a significant new corporate policy by making a substantial investment. Nothing turns on the corporate policy being identified with a substantial corporate investment, but we think it useful as an expositional device. In the context of our model, the corporate policy opportunity is a one-time event. Thus, if the investment is not made and the policy is not implemented, the opportunity will disappear.

We assume that since this is a new opportunity that is only being considered for adoption, the managers are more fully informed about the potential returns associated with it than are outside investors. Investors are not fully informed, but make Bayesian predictions as to the value of the firm's new investment opportunities. In making the model more supportive of the shareholder choice legal regime, we assume that investors are aware of the private benefits taken by the managers. 
In our model, executive compensation has two components: first, a fixed component, $\mathbf{b}$, that is independent of the share price and second, a variable component that is determined by the managers' percentage interest, $\mathbf{s}$, in the residual value of the firm. The various types of benefits actually received by managers can be interpreted as being part of either $\mathbf{b}$ or $\mathbf{s}$ depending on whether they vary with the value of the firm. Fixed compensation and "perks" unrelated to the value of the firm are in $\mathbf{b}$. Stock ownership or options awarded to the managers determine $\mathbf{s}$.

Once the compensation structure is fixed, we can identify the private benefits entirely with the $\mathbf{b}$ component. ${ }^{15}$ Strictly speaking, the managers' compensation includes their opportunity wage. However, it is useful to envision the opportunity wage component as a subtraction from the cash flows of the existing assets and of the new investment. With the managers' opportunity cost incorporated into the free cash flows, the $\mathbf{b}$ and s components are thus interpretable as quasi-rents. The difference between $\mathbf{b}$ and $\mathbf{s}$ is that the managers' and investors' interests are partially aligned with respect to $\mathbf{s}$, but not with $\mathbf{b}$. The alignment of interest with respect to $\mathbf{s}$ follows from the fact that the $\mathbf{s}$ component provides managers with a pro rata share of the firm's value. On the other hand, the $\mathbf{b}$ component is deducted off from the value of the firm and is paid to or taken by the managers.

In setting corporate policies, the interests of shareholders and managers are aligned when policy decisions only affect the value of the corporation and not the managers' private benefits. Many policy decisions only affect the value of the firm and agency cost problems do not arise with respect to these policies. The misalignment of interest is in sharpest relief in the case of hostile takeovers. Managers will be reluctant to adopt corporate policies that are in the best interest of the corporation if doing so reduces their expected private benefits through a reduction in their expected job tenure.

We start from an equilibrium position in which all firms are correctly valued and there is no outstanding private information. In equilibrium we thus have strong-form efficiency and the market and managers agree about the present value of the firm's cash flows and the value of its growth opportunities. In this equilibrium there are no existing takeover opportunities. The market knows the array of agency costs in each firm and these are also priced into the value of the corporation. Consequently, whatever hostile tender offers are profitable at the current array of market prices, available technologies, economic outlook, etc. have occurred. Of course, a bid will be profitable only if the bidder can cover the cost of bidding. The fact that no bids are profitable in the initial equilibrium implies that b cannot exceed this cost. In fact, we assume that managers know the cost of a bid and choose $b$ to equal it so as to avoid becoming a target while extracting the maximum possible private benefit.

We recognize that there is an immense variety of events that can disturb this initial equilibrium. We suppose that the investors and management also recognize that the initial equilibrium will be disturbed. But we suppose that it is impossible for either investors or managers to anticipate with any degree of useful precision the nature of the possible innovations. For our purposes, we focus the discussion on cases where the 
equilibrium is disturbed by an unanticipated one-time innovation that brings a new corporate policy or investment opportunity to the firm. Because this new innovation is unanticipated, its expected value is not included in the present value of the firm's existing growth opportunities. As discussed later, the fact that the innovation is unanticipated is also important for the interpretation of the results derived from the model.

Once this innovation occurs, investors and managers know that it has occurred but managers know more than the financial market about the returns to this investment opportunity. The policy is implemented if the managers, using their superior information, decide to make the investment. Although the investors don't know as much as the managers, they do know that the managers are better informed. The managers' policy decision provides investors with a potential signal of the managers' information. Investors are Bayesian and use this signal to update their beliefs about the potential returns to the investment opportunity. The signal may, of course, be uninformative. In our model, hostile tender offers occur at this point.

In the model, a takeover occurs if the potential bidder is able to obtain a higher return from the new investment than current management. The case of primary interest is when this is possible because of the existence of synergies between the new investment and the assets already controlled by the potential bidder. The possibility that a bid will arise because of these synergies implies that, when the managers implement the new policy by making the investment, they face the risk of losing control of the firm and losing the private benefits made possible by that control. This is a risk only in a shareholder choice regime. It is the desire to avoid this risk that can lead the managers to fail to implement the policy even when they know that the returns to its implementation justify the investment. In a management discretion regime, managers make the investment because they know that a hostile bid can be defeated. In this case, defeat of the bid is not in the shareholders' interest. However, if managers could not defeat such bids they would not be willing to implement the new corporate policy when they should. Thus, it is in the interest of shareholders to bear the cost imposed on them by the managers when they choose to reject hostile bids.

We assume that the price offered by the bidder equals his true valuation of the firm net of bidding costs. Again this is an assumption that can be relaxed at the cost of some complication in the arguments but without affecting the conclusions.

Having briefly described the agency problem that can emerge in a shareholder choice regime, we want to comment on the impact it might have on the initial equilibrium in which we suppose the firm begins. As we noted earlier, in the initial equilibrium, investors and managers are aware that new corporate policy opportunities can arise. In addition, they can also be aware that the agency problem we describe can occur when unanticipated new opportunities emerge. The fact that these opportunities cannot be anticipated by investors implies that the distribution of outcomes and the possible costs of the agency problem with any useful degree of precision. As a consequence, the initial equilibrium is unaffected by the existence of the agency problem. In particular, there are no attempts by outside investors to bid for the firm with the aim of taking it private so as 
to avoid the agency problem. There is, hence, no need for managers to reduce private benefits further to eliminate the possibility of such bids.

\subsection{Formal description of the model}

In the formal description of the model it is convenient to identify the implementation of the new corporate policy with the decision to invest. It is also convenient to refer to the decision to invest as the decision to exercise an investment option.

If the investment is made, the firm is worth

$$
V(x)=c f+C+x-I-b,
$$

where

$c f=$ the PV of the future cash flows of the firm's previous investments, which includes reinvestment in future growth opportunities at some ROE that is known to the market,

$C=$ the firms' cash on hand,

$I=$ the cost of exercising the firm's investment option,

$b=$ the private benefits extracted by the manager,

$x=$ the PV of the cash flows of the investment and is the realization of a random variable $\tilde{x}$.

Written in the general form we use, $x$ is open to a number of different interpretations. Recall that the Gordon growth model yields the expression

$$
x=\frac{C F}{r-g}
$$

where $C F$ is the first period cash flow, $\mathrm{g}$ is the growth rate of the cash flows and $\mathrm{r}$ is the discount rate. Thus, the uncertainty about $x$ can arise because of uncertainty about the first period cash flow, the growth rate or the discount factor.

We assume that, at the time the investment decision is made, $x$ is known to the firm's managers, but not to the market and that the market simply knows $\bar{x}=E \tilde{x}$.

The value of the firm is thus the sum of two parts. The first component is composed of the existing assets and the reinvestments of the cash flows generated by the existing assets. This component includes the present value of the future growth opportunities based on the existing corporate policy. We assume that these growth opportunities are known to investors and are thus entirely priced into the firm's market value. The existing corporate policy thus has a known growth rate (g) and discount rate (r) unique to the existing corporate policy. 
If no new corporate policy option is open to the firm or if such an opportunity is available but is forgone by the managers, the firm is worth

$$
V_{n}=c f+C-b .
$$

In that case, the managers and the market are in agreement that the value of the firm is $V_{n}$. In other words there is strong-form efficiency in that the share price of the common stock will be the value that generates an enterprise value equal to $V_{n}$.

The second component is composed of the newly available corporate policy opportunity. This policy option has its own expected growth rate and discount rate, which is captured by the term $x$, and by the cost $I$. As noted earlier, the possible emergence of this particular new "growth opportunity" is unanticipated and, therefore, not included in the calculation of the present value, $c f$.

We focus on the case in which

$$
x-I>0
$$

and

$$
\bar{X}-I<0 .
$$

In this case, the managers know the corporate policy should be implemented because the investment has a positive net present value $(N P V>0)$, while the market has the opposite view, believing the investment is net present value negative. When referring to the investment as an option, we describe the case in which the net present value is positive as the case in which the investment option is in the money. The negative net present value case is, thus, the case of an investment option that is out of the money.

Immediately after the investment is made, there will be a brief period in which strong-form efficiency fails in that the managers will know the firm is worth $V(x)$, while the market will believe the firm is worth $V(\bar{x})$. We suppose that soon after the investment is made, the market will quickly learn what the manager knows and will also value the firm at $V(x)$. At that point, strong-form efficiency is restored.

Importantly we also assume that if the investment opportunity is not taken, the market does not come to realize its value or whether it was positive NPV. In other words, strong-form efficiency is satisfied in the traditional sense. That is, the firm is correctly valued on its existing corporate policy and the current and future assets of that policy. In spite of this, the true value of the corporate policy option that has become available but rejected is not and never will be incorporated into that value.

We assume that outside investors realize that the agency problem exists and that because of it the managers may not implement new corporate policies that should be implemented. They never actually know, however, whether a specific corporate policy 
opportunity was rejected because of the agency problem or because it was an opportunity not worth taking. If outside investors could anticipate the arrival of new corporate policy opportunities, and could also accurately assess the probability of their arrival and of their being positive NPV investments, they would be willing to pay less for the firm. In particular, the firm's value would be reduced by the expected present value of the future positive NPV opportunities that the market expects the firms' managers to reject because of the agency problem. As noted above, we follow Grossman and Hart, in assuming there are many future contingencies that cannot be foreseen by the market. In particular we assume that it is impossible for market participants to assess the probability of the arrival of new corporate policy opportunities or even to envision the possible corporate policy opportunities that might arise.

Thus, outside investors know that an investment opportunity has become available and not been taken. They don't know whether it was in the money. Not knowing this and not knowing the likelihood of this situation arising again, it is impossible for them to calculate how much the firm should be discounted because of the possible reoccurrence of this event.

Due to the presence of agency costs, managers are assumed to make the decision that maximizes their compensation. However, since managers own a share of the firm, their interests are partially aligned with those of the shareholders. We let

$$
s=\text { the fractional share of the firm owned by the manager. }
$$

The managers' interests are not completely aligned with those of shareholders because, as managers, they also extract private benefits that reduce the value of the firm. We designate the private benefits that do not vary directly and proportionally with the value of the firm by the term $b$.

The managers' total compensation is, therefore,

$$
b+s V
$$

Allowing for the fact that private benefits are likely to differ depending on whether the legal regime is one of shareholder choice or management discretion, $b$ can equal either $b_{s}$ or $b_{m}$, where

$b_{s}=$ the private benefits extracted by the manager under shareholder choice and

$b_{m}=$ the private benefits extracted by the manager under managerial discretion,

A conclusion of the debate over shareholder choice versus management discretion is that the private benefits associated with managerial discretion are larger than the benefits the managers are able to extract in a shareholder choice regime. That is, we assume that 


$$
b_{m}>b_{s}
$$

The rationale is that managers set $b_{s}$ below the cost that a hostile bidder would have to pay in transaction costs to takeover the firm. If managers extract benefits in excess of those costs, the resulting reduction of the firm's value will attract hostile bidders and the managers will lose control of the firm and the corresponding private benefits. Thus we can interpret $b_{s}$ as the expected cost of a takeover bid. This means that whenever a bidder values the firm at an amount that exceeds its market value by more than $b_{s}$, a bid will occur.

What sets the value of $b_{m}$ ? In a world where managers can just say no to tender offers, but still owe fiduciary duties to the corporation, $b_{m}$ would be determined by what private benefits managers could realize without running afoul of their fiduciary duties.

In section 4, we introduce a third legal regime, where managers can say no to tender offers, but must allow a full and free proxy contest with the bidders. In this case, the private benefits of the managers would be determined as in the shareholder choice regime but would be higher reflecting the greater costs to the bidder of conducting a combined tender offer/proxy contest battle for control. We define

$$
b_{p}=\text { the private benefits extracted by managers under the mixed rule where }
$$
bidders could succeed in winning control by combining a tender offer with a proxy contest.

We assume.

$$
b_{m}>b_{p}>b_{s}
$$

\section{The Synergies Model}

This section presents a very simplified exposition of the agency problem. We therefore use a highly stylized model to illustrate how the problem can arise. It is to be expected that when the agency problem actually occurs the setting will be more complex, but the essential features that give rise to the problem will be as described in our simple model. We assume that the corporate policy generates one of two possible outcomes, one yielding a high $x$ and a positive NPV and the other resulting in a low $x$ and thus a negative NPV. Specifically,

$$
x \in\left\{X_{L}, x_{H}\right\}
$$

where

$$
x_{L}<x_{H}
$$


and where

$$
x_{L}-I<0<x_{H}-I
$$

In this model, we assume that when the firm adopts a new corporate policy it may increase its attractiveness to a potential bidder. This may happen because the new policy creates a new array of potential synergies and these synergies are recognized by potential bidders. It may happen simply because the potential bidders are better able to realize profits from the investment required to implement the new corporate policy. For simplicity, we discuss this case, using the synergies interpretation. For the same reason, we assume that the value of the synergies created for the bidder by the investment are the realization of a random variable $\tilde{\sigma}$, where

$$
\begin{aligned}
& \tilde{\sigma} \in\left\{0, \sigma_{H}\right\} \\
& \sigma_{H}>0,
\end{aligned}
$$

and

$$
\operatorname{Pr}\left(\tilde{\sigma}=\sigma_{H} \mid \tilde{x}=x_{H}\right)=\varphi>0 .
$$

The term $\varphi>0$ represents the probability that positive synergies are created for a potential bidder by the managers’ new corporate policy.

As noted we are going to consider the situation in which the managers know that

$$
x-I>0
$$

and the market believes that

$$
\bar{X}-I<0
$$

In this case, $x=x_{H}$.

Whether $\varphi>0$ generates an actual hostile bid will vary depending upon whether the legal regime is shareholder choice or management discretion.

\subsection{The Case of Shareholder Choice}

The case of interest is where both $b_{s}$ and $\varphi$ are relatively high and $s$ is relatively low; that is, the managers are able to take large private benefits (because the transaction's takeover costs are high), there is a good chance that there are material synergies, and managers don't have claims to a significant fraction of the firm's shares. In the

equilibrium that arises under these conditions, the managers forgo the new corporate 
policy even when $x=x_{H}$ and the policy has a positive $N P V$. Although the implementation of a new corporate policy constitutes a potential signal, the fact that managers never invest in this equilibrium implies that the lack of a new corporate policy is uninformative. We have a pooling equilibrium in which there is no investment when $x=x_{H}$ or $x=x_{L}$. As a result the outside investors' initial beliefs are their equilibrium beliefs. In describing how this equilibrium arises, it is necessary to make some assumption about what outside investors would believe if they did observe the implementation of a new corporate policy. Specifically, we assume that, if a new corporate policy is adopted, outside investors would infer that $x=x_{H}$ and $N P V>0$.

We first describe the conditions under which the managers decide not to invest when they know that $x=x_{H}$, that is, the investment option is in the money. The reason that the managers will not make the investment is that they would lose control of the firm. Note that if the managers were to choose to invest in that case, the market would value the firm at

$$
c f+C+x_{H}-I-b_{s} .
$$

But in the event that $\tilde{\sigma}=\sigma_{H}$ the bidder would value the firm at

$$
c f+C+\left(x_{H}+\sigma_{H}\right)-I
$$

and make a bid at that price minus the cost of a bid which is $b_{s}$. The bidder is thus willing to bid

$$
c f+C+\left(x_{H}+\sigma_{H}\right)-I-b_{s} .
$$

In a shareholder choice regime that bid cannot be rejected and the managers would lose control of the firm. In that event, the managers' compensation would be

$$
s\left[c f+C+\left(x_{H}+\sigma_{H}\right)-I-b_{s}\right] .
$$

That is, the managers' compensation would only be the value of their investment in the firm and private benefits $b_{s}$ would be lost. Note that $b_{s}$ is subtracted off from both equations: the value of the firm without a bid and the value of the bid. In the former case the subtraction is made to reflect the market's knowledge of the managers' private benefits. In the later case the subtraction is made to reflect the cost of the bid.

Recall, however, that with probability $1-\varphi, \tilde{\sigma}=0$ and no bid occurs. In that case, the managers would retain their private benefits so that their compensation would be

$$
b_{s}+s\left(c f+C+x_{H}-I-b_{s}\right) \text {. }
$$


When the managers know that $x=x_{H}$ and invest, they do not yet know if the synergies actually will be generated for the bidder. Thus, the expected compensation of the managers when they invest is

$$
(1-\varphi) b_{s}+s\left[c f+C+\left(x_{H}+\varphi \sigma_{H}\right) f-I-b_{s}\right] .
$$

This means that when $x=x_{H}$ and $b_{s}$ and $\varphi$ are both large, the expected compensation associated with not investing exceeds the expected compensation earned by investing. The exact condition is

$$
\varphi b_{s}>s\left[\left(x_{H}+\varphi \sigma_{H}\right)-I\right]
$$

Consequently, the corporate policy opportunity is forgone where the managers receive high private benefits (even in a shareholder choice regime), and the probability of synergies arising out of the potential investment are also high. In this case, there is a misalignment of interest between shareholders and managers because the managers have not only more to lose if the firm is taken over, but also because of a greater probability of losing control.

In the other possible case, $x=x_{L}$ and the investment option is out of the money. Since managers own a fraction of the firm, they will not make investments that reduce the value of the firm and they choose not to implement the new corporate policy. In this case, there is no misalignment of interest. ${ }^{16}$ Consequently, under the conditions we are considering (both $b_{s}$ and $\varphi$ are large), the managers do not adopt the new corporate policy whether $x=x_{H}$ or $x=x_{L}$. The fact that the investment is not made in either case means that we have a pooling equilibrium whereby investors cannot learn anything when managers do not make the investment.

In the pooling equilibrium described, the outside investors never have an opportunity to learn that the manager chose not to exercise an investment option that was in the money simply because the investment is never made. In equilibrium, the firm is correctly valued at

$$
c f+C-b_{s}
$$

Since the firm is correctly valued based on all private as well as public information, strong-form efficiency holds in equilibrium!

Before leaving the case of shareholder choice it is useful to note that, when

$$
\varphi b_{s}<s\left[\left(x_{H}+\varphi \sigma_{H}\right)-I\right]
$$


the equilibrium will be one in which the managers invest when the investment option is in the money and don't invest when it is not. In this equilibrium, outside investors will interpret the managers' decision not to invest as a signal that they know that the option is out of the money and interpret the decision to invest as a signal that the option is in the money. This is the same equilibrium as the one that arises in the case of managerial discretion, the case we consider next. Under these conditions, the bid does take place and is successful when the synergies actually arise. In other words, in this case the managers do implement the new corporate policy because the value of the policy to them as shareholders exceeds the possibility of lost private benefits. Alignment of interest occurs, but possibly because of the high stock options granted to managers in order to increase their personal gains from any merger.

\subsection{The Case of Management Discretion}

Management discretion means that the managers can decide to maintain takeover defenses that prevent shareholders from tendering into the bidder's offer. Since they are no longer concerned about losing control of the firm to a hostile tender offer, the manager's interests are aligned with the shareholders when choosing the firm's corporate policy. Now, the equilibrium is one in which the managers invest when the investment option is in the money and don't invest when it is out of the money. The outside investors believe that the investment option is out of the money when they observe the managers choose not to invest and they believe the option is in the money when the managers are observed to invest.

When the option is in the money, and the managers invest, they face no risk of a bid and, as a consequence, their compensation is

$$
(1-s) b_{m}+s\left(c f+C+x_{H}-I\right)
$$

If they choose not to invest, their compensation is

$$
(1-s) b_{m}+s(c f+C) .
$$

Since

$$
x_{H}-I>0 \text {, }
$$

the managers prefer to invest.

When the option is out of the money, and the managers invest, they face no risk of a bid and, as a consequence, their compensation is

$$
(1-s) b_{m}+s\left(c f+C+x_{L}-I\right) .
$$

If they choose not to invest, their compensation is 


$$
(1-s) b_{m}+s(c f+C) \text {. }
$$

Since, in this case,

$$
x_{L}-I<0,
$$

the managers prefer not to invest.

Consequently, when managers can defeat uninvited tender offers, they will adopt whatever corporate policies maximize the value of the firm. This is the major benefit of a management discretion regime. It occurs because managers own some value of the $s$ and making the correct value maximizing decisions poses no threat to their private benefits $b_{m}$

\subsection{The Legal Systems Compared}

In the case where synergies are present and the corporate policy opportunity is in the money, the shareholder choice and management discretion regimes generate different outcomes for shareholders if the private benefits of control are significant and the risk of a new corporate policy generating a hostile bid is high. Under a shareholder choice regime, the managers choose to avoid the risk of losing their private benefits as the result of a successful hostile bid by choosing not to implement the new policy even though they know they are making a choice that is not in the interests of shareholders. In this case, the shareholders' interest in the corporation is always the value of the corporation under the existing or prior corporate policy, minus the private benefits taken by the managers

$$
c f+C-b_{s} .
$$

Under managerial discretion the corporate policy opportunity is always adopted when it is in the money, but the hostile tender offer is rejected if it occurs. Hence, the shareholders get

$$
c f+C+\mu_{H}\left(x_{H}-I\right)-b_{m},
$$

where $\mu_{H}$ is the probability of $\tilde{x}=x_{H}$. The shareholders are clearly better off under management discretion if

$$
\mu_{H}\left(x_{H}-I\right)>b_{m}-b_{s},
$$

where the left side of the above inequality is the expected value of the investment option if it is exercised when it is in the money. This condition means that shareholders are better off under management discretion if the expected benefits from the new corporate policy, ignoring the possible forsaken gains from a potential takeover, exceed the additional agency costs of managerial discretion. 
It should be noted that in both legal regimes the shareholders lose the expected value of the synergies. Under shareholder choice this happens because the investment is never made even when it should be. Hence the opportunity to make use of the synergies does not arise. Under managerial discretion, the investment is made, but the synergistic bid is rejected. If these bids were not rejected, the firm would be worth

$$
c f+C+\mu_{H}\left(\left[x_{H}+\varphi \sigma_{H}\right]-I\right)-b_{m}
$$

to the shareholders. Thus, the total cost of the new agency problem we have identified as arising in a shareholder choice regime is

$$
\mu_{H}\left(\left[x_{H}+\varphi \sigma_{H}\right]-I\right)
$$

the expected value of the investment option. By switching to a managerial discretion regime, only part of this agency cost is avoided; namely

$$
\mu_{H}\left(x_{H}-I\right) \text {. }
$$

What is lost in both regimes is

$$
\mu_{H} \varphi \sigma_{H},
$$

the expected value of the synergies.

In the comparison of the legal regimes that emerges from the model as described above, the cost borne by shareholders in a managerial choice regime is the increase in the agency costs

$$
b_{m}-b_{s} \text {. }
$$

This term omits a cost of managerial discretion that needs to be discussed to complete our analysis. This cost arises because there of the possibility that a bidder will emerge who is able to put the firm's current assets to better use, perhaps because of synergies, than the current management. As distinct from our earlier discussion, which involves an innovation directly affecting the managers' corporate policy options, this is an innovation directly affecting the bidder's options as they relate to the existing assets of the managers. Under a shareholder choice regime, bids made by these bidders will be successful and the current assets will as a consequence be moved to their best use. Under a management discretion regime such bids will be defeated. As a result shareholders will suffer and total welfare is reduced because the firm's existing assets will not be used efficiently. If we let $\rho$ be the expected increase in the value of the firm's existing assets when bidders emerge who can put them to better use, then the total loss to shareholders under a managerial discretion regime is 


$$
b_{m}-b_{s}+\rho,
$$

and it is this that must be compared to the cost,

$$
\mu_{H}\left(x_{H}-I\right)
$$

incurred under a shareholder choice regime. The revised condition under which management discretion is preferred by shareholders is

$$
\mu_{H}\left(x_{H}-I\right)>b_{m}-b_{s}+\rho
$$

As noted, the loss of $\rho$ is an inefficiency that reduces social welfare. The same is true of

$$
\mu_{H}\left(x_{H}-I\right)
$$

In contrast,

$$
b_{m}-b_{s} \text {. }
$$

is a loss to shareholders but a gain to managers and, as such, it does not represent an inefficiency.

\subsection{Going Private as a Solution to the Agency Problem}

Since privately held firms avoid the management-shareholder conflict, they are not afflicted with agency problems. It would seem, therefore, that "going private" transactions - in an anticipation of the existence of the agency problem-could provide a solution to the particular agency problem that we have identified as arising in a shareholder choice regime. As we now argue, however, under the assumptions we have made, there are limits to the extent to which the going private transaction can eliminate the costs of this agency problem. In particular, we have assumed that the potential investment opportunities whose emergence gives rise to the agency problem are "unanticipated one-time opportunities". Let's first discuss how taking the firm private could either avoid or reduce the cost of the agency problem if these assumptions were not satisfied.

Suppose first that outside investors could, in advance, accurately assess the agency problem's expected future cost. They would then be willing to pay a premium for the firm with the aim of taking it private and avoiding the problem's future occurrence. But bids to take the firm private could be made unprofitable in the initial equilibrium if the managers reduced the private benefits they extracted to the point at which the cost of those benefits equaled the cost of a bid minus the expected future agency cost. The effect of this reduction in the private benefits extracted by managers is a reduction in the traditional agency cost borne in a shareholder choice regime. It does not eliminate the agency problem we have identified but it does reduce the total agency cost of a 
shareholder choice regime. If, however, the expected future agency costs were very high, the managers might be unable to make private equity bids unprofitable in the initial equilibrium even by extracting no private benefits at all. In such cases, the agency problem would, indeed, be eliminated by bidders who could profit by taking the firm private.

Specifically, suppose that, in a shareholder choice regime, outside investors did anticipate the emergence of the potential new investment opportunity and could accurately assess the probabilities we have discussed as well as the probability of the emergence of the investment option, which we denote by $\psi$. In that case, a bidder who intended to take the firm private could make an expected profit, taking into account the cost of the bid, by buying the firm, making the investment if the opportunity to do so arose and if it was a positive NPV investment. He could then sell the firm if the synergy value of the new assets for another bidder were positive. The expected cost of the agency problem avoided by taking the firm private is

$$
\psi \mu_{H}\left(x_{H}+\varphi \sigma-I\right),
$$

and this minus of the cost of a bid is also the profit to the bidder who takes the firm private. Even when outside investors accurately assess the probabilities of the investment opportunity arising, being a positive NPV investment and creating synergies for another bidder, the managers of the firm can prevent a bid by reducing the private benefits by the amount

$$
\psi \mu_{H}\left(x_{H}+\varphi \sigma-I\right) .
$$

When

$$
\psi \mu_{H}\left(x_{H}+\varphi \sigma-I\right)
$$

exceeds the cost of a bid the managers cannot prevent the firm from being taken private in the initial equilibrium even if they reduce the private benefits they extract to zero. In that case, the firm will be taken private and the agency problem will fail to arise.

Note, however, that when, as we have assumed, the emergence of the new policy opportunity is "unanticipated" and investors are unable to accurately assess the expected agency cost,

$$
\psi \mu_{H}\left(x_{H}+\varphi \sigma-I\right),
$$

in advance, it will be impossible for private equity bidders to know what price to pay for the firm. In such a situation, taking the firm private becomes ineffective as a device for eliminating or reducing the impact of the agency problem. Also, as we noted earlier, the outside investors' inability to accurately assess the expected cost of the agency problem 
arising under shareholder choice implied that the potential for the problem to arise had no impact on the initial equilibrium.

The assumption that the investment opportunity is a one time opportunity that is lost if it the investment is not made is also important. If it were possible to revisit the decision to make the investment at a later time, a bidder who had observed the manager's decision not to invest could take the firm private, learn what managers know about the investment and make the investment if it were a positive NPV opportunity. In that way they could realize the expected gains

$$
\mu_{H}\left(x_{H}+\varphi \sigma-I\right)
$$

\subsection{Golden Parachutes as a Solution to the Agency Problem}

The agency problem we have discussed arises because managers seek to avoid hostile bids that result in the loss of the private benefits the managers extract from the firm. Consequently, it might seem that the adoption of a golden parachute could resolve the entrenchment problem by compensating managers for the loss of their private benefits should their firm be taken over. In fact, in the context of our model, the introduction of golden parachutes actually makes shareholders worse off by raising the cost of a bid and thus worsens rather than resolves the agency cost problem. This means that the introduction of golden parachutes has only negative consequences; there are no positive benefits. As a consequence, the introduction of golden parachutes raises the appeal of a management discretion regime relative to shareholder choice.

The problem is that when bidders are forced to pay for a golden parachute, the cost of a bid rises by the cost of the parachute and this makes it possible for managers to extract even higher private benefits without attracting a bid. In fact, the managers can increase the private benefits they extract by exactly the amount of the parachute's cost. Thus, when a parachute is introduced the benefits lost are inflated by exactly the value of the parachute they receive. When there is a parachute and the managers compare the private benefits they might lose in a takeover to the compensation they could receive in a takeover, the private benefits they anticipate losing are inflated by the parachute's value and the inflation in these benefits exactly cancels the value of the parachute received when the takeover occurs.

Formally, shareholder choice creates an agency problem because managers expect to lose private benefits, $b_{s}$, when a hostile bid succeeds. As presented our argument assumes the absence of any "golden parachutes," that promise managers compensation in the event of a change in control. If the firm does have a golden parachute in place, the cost of a bid will include its cost, call it $p$. If $b_{s}$ are the private benefits extracted when there is no golden parachute, then the private benefits extracted when the cost of a bid includes $p$ will rise to $b_{s}+p$. This means that the managers are able to capture the value of the parachute in the form of additional private benefits even if no bid occurs. It also means that the private benefits lost if a bid occurs are larger by exactly the amount of 
the parachute paid when a takeover occurs. When there is a parachute, the condition under which the agency problem arises under shareholder choice is

$$
\varphi\left(b_{s}+p\right)>s\left[\left(x_{H}+\varphi \sigma_{H}\right)-I\right]+\varphi p,
$$

but this is the same condition under which the agency problem arose without a parachute. This means that under shareholder choice and with a parachute, the managers will misbehave in exactly the same situations as they would if there were no parachute.

The introduction of the parachute also has no impact on the situations in which a bid occurs. Without a parachute a bid occurs when, net of the bidding cost, the bidder's value of the firm exceeds the firm's market value which includes a discount for the private benefits extracted. Since the financial market deducts agency costs from the value of the firm, the market value of the company falls by $p$. But this fall in the cost of the shares is exactly matched by the rise in the cost of a bid. Since the cost of the bid is subtracted from the bidder's valuation of the firm, net value of the firm to the bidder is unchanged. Hence there will be neither fewer nor more bids.

Those who prefer shareholder choice over management discretion do so because of the fact that managers are able to extract smaller private benefits when faced with the threat of takeovers that cannot be resisted under shareholder choice. Indeed, in our model the private benefits managers can extract in a shareholder choice regime are restricted to equal the cost of a bid. In this setting the advantage of a shareholder choice regime is diminished when the cost of a bid, and the private benefits extracted by managers, are inflated by the introduction of a golden parachute. Formally if we continue to interpret $b_{s}$ as the cost of a bid excluding the value of the golden parachute, then a golden parachute worth $p$ to the managers raises the cost of a takeover and hence the private benefits extracted by managers from $b_{s}$ to $b_{s}+p$. This increase in the private benefits managers extract are an added cost to shareholders under shareholder choice.

The apparent motivation for a golden parachute is lacking in a management discretion regime. But if a golden parachute is introduced into such a regime it should have no impact on the private benefits extracted. In that case, the private benefits are $b_{m}$ and independent of the cost of a bid. Thus, the increase in the cost of a bid caused by the introduction of a golden parachute has no effect and managers continue to extract $b_{m}$. Hence the introduction of a golden parachute in each regime reduces the extra private benefits extracted in a management discretion regime from

$$
b_{m}-b_{s}
$$

to

$$
b_{m}-b_{s}-p
$$

This, of course, means that the introduction of a golden parachute diminishes the relative attractiveness of the shareholder choice regime while, as we have already noted, 
yielding no benefits in terms of eliminating the agency problem we have identified as arising in a shareholder choice regime.

\section{When the Alternative to Shareholder Choice is the Proxy Vote Rule}

In this section, we analyze more rigorously what is meant by the terms "shareholder choice" and "management discretion" and discuss whether the conclusions we reach with respect to management discretion hold once one recognizes that hostile tender offers that are held-up, on account of a poison-pill, can eventually succeed once the bidder wages and wins one or two (in the case of a staggered board) proxy contests.

In their current version, neither the shareholder choice nor the management discretion is a pure form. For example, a pure shareholder choice regime would be the rule first favored by Easterbrook and Fischel (1981) when they argued for complete management passivity in the face of a takeover. This argument is consistent with strongform efficiency. Since the market price always incorporates all information both public and private, any hostile tender offer has to move resources to their more valued use. Poison pills or other defensive strategies would primarily have the effect of raising the cost of a bid. In our model as we have so far developed it, the ability to deploy poison pills has the effect of raising the private benefits that managers can extract from $b_{s}$ to $b_{m} \cdot 17$

Instead, shareholder choice has come to be recognized as a rule that incorporates the Chancery Court's Interco doctrine. Under Interco a target firm could indeed maintain a poison pill long enough to negotiate a better price or advance a superior option. But after an interval long enough to give managers a chance to proffer alternatives, the poison pill would have to be lifted.

The best case for an Interco rule over a complete passivity rule is that by providing managers with a bargaining tool it creates a disclosure-rich environment. In doing this, the Interco doctrine helped move financial markets from being semi-strong to being strong-form efficient. That is, after a bid is made shareholders learn (more of) what managers knew but have not previously revealed.

Pure management discretion can be identified with an interpretation of TimeWarner that allows managers to "just say no" to a tender offer. The problem with this interpretation is twofold: first the Delaware courts have never adopted even an implicit "just say no" rule and second, since shareholders ultimately get to choose the directors, the shareholders do get to eventually decide the fate of the managers. Instead, management discretion has come to be recognized as a rule that builds layers of defensive strategies to a point where a would-be bidder would be effectively deterred.

How do these more mixed regimes operate in the context of our model? ${ }^{18}$ In fact, a regime that facilitates a proxy contest for control will, in some cases, operate in a manner similar to shareholder choice, but with higher costs. That is, under some conditions, a so-called management discretion regime degenerates into a very costly 
shareholder choice regime. However, under certain very plausible assumptions, we can generate the same results as those obtained in a management discretion regime even when there is a need for annual elections.

The factor that is most important in determining which case obtains is the expected cost of acquiring a firm by means of a proxy contest and how that cost relates to the private benefits extracted by management and to the value of the synergies a new investment project might generate for a potential bidder. We let $\gamma$ equal the costs of a takeover that requires a proxy contest. It is natural to assume that $\gamma$ is significantly higher than the costs of a successful hostile tender offer in a shareholder choice regime. This means that $\gamma>b_{s}$ where, it will be recalled $b_{s}$ is the value of the private benefits extracted by managers in a shareholder choice regime and is chosen by managers to equal the cost of a takeover in that regime. It will also be recalled that, in a management discretion regime, managers are able extract larger private benefits than is possible under shareholder choice. We have labeled these benefits $b_{m}$ and they are the maximum private benefits that managers can extract from the firm given the constraints imposed by the managers' fiduciary duties. Thus $b_{m}>b_{s}$. Now $\gamma$ may or may not rise to the level of $b_{m}$. When $\gamma$ is below $b_{m}$, the private benefits managers are able to extract, which we call $b_{p}$, will be limited to $\gamma$ for reasons that are the same as those discussed in the case of shareholder choice. In this case, the agency problem is not eliminated when a shareholder choice regime is replaced by one that introduces a proxy contest requirement. Indeed, the only effect of the introduction of a proxy contest requirement is to raise the agency cost from $b_{s}$ to $b_{p}=\gamma$. To demonstrate that this is so we simply replace $b_{s}$ with $b_{p}=\gamma$ and use the same argument as that used above for the case of shareholder choice.

The same conclusion holds and the argument leading to this conclusion is again essentially the same as that used in the case of shareholder choice when $\gamma>b_{m}$ as long as $\gamma$ is only slightly above $b_{m}$. When $\gamma$ exceeds $b_{m}$, managers are unable to raise their private benefits to the level of $\gamma$. In this case, their private benefits will be limited to $b_{p}=b_{m}$. Recall that the agency problem can arise as long as the investment under consideration creates the possibility that bidders can obtain synergistic gains by acquiring the new assets. When $\gamma$ exceeds $b_{m}$, the agency problem will arise if such bids actually present a threat to management. That will happen in this case, if the value of the potential synergies, $\sigma_{H}$, plus the private benefits $b_{m}$ exceed the cost $\gamma$ of obtaining the firm via a proxy contest; formally, if $\gamma<b_{m}+\sigma_{H}$. When this condition holds, the bidder can pay a premium for the firm that enables him to profit from a bid. Managers know that a corporate policy opportunity that raises the likelihood of there being synergistic benefits will lead to a bid. Under the new regime, the managers can thwart the bid at the tender offer stage, but the bidder will continue to the proxy contest and win control. The threat of this possibility deters the managers from making the investment and there is still an agency problem. The impact of the new legal rule is thus limited to raising the costs of a takeover, while otherwise losing the benefits of management discretion. 
In the cases discussed above, the agency problem is more likely to occur because of the increase in the private benefits the managers are able to extract. As we have noted, the managers will extract

$$
b_{p}=\min \left\{b_{m}, \gamma\right\}>b_{s} .
$$

The agency problem will occur in the proxy contest regime when

$$
\varphi b_{p}>s\left[\left(x_{H}+\varphi \sigma_{H}\right)-I\right]
$$

The agency problem occurs under shareholder choice when

$$
\varphi b_{s}>s\left[\left(x_{H}+\varphi \sigma_{H}\right)-I\right]
$$

Because $b_{p}>b_{s}$, the agency problem occurs in the proxy regime whenever it occurs in the shareholder choice regime. There will be some cases in which

$$
\varphi b_{p}>s\left[\left(x_{H}+\varphi \sigma_{H}\right)-I\right]>\varphi b_{s}
$$

and, in those cases, the agency problem arises in a proxy contest regime but not in a shareholder choice regime.

When the value of the potential synergies, $\sigma_{H}$, plus the private benefits $b_{m}$ exceed the cost $\gamma$ of obtaining the firm by means of a proxy contest; i.e., when $\gamma>\sigma_{H}+b_{m}$, the high cost of acquiring the firm in this regime makes it impossible for the potential bidder to make a bid for the firm that exceeds its market value. This eliminates the threat of a bid. In this case, the managers can effectively say no to a bid and be assured that when they do, a proxy contest will not ensue. Since we assume efficient markets throughout the argument, the managers know this fact just as the bidder knows the value to it of the new investment made by the managers. Consequently, the managers can make the investment knowing that the costs of bidding will protect them from an uninvited tender offer. The managers will thus maximize their wealth, as in the above model, by maximizing the value of the firm without fear of a takeover. The outcome is thus the same as in management discretion.

As we have modeled this regime, it will, in some cases, operate as a management discretion regime. In other cases, it will result in outcomes that are similar to, but worse than, shareholder choice. The outcome produced in a particular case will depend on the value of the possible synergies. When synergies are likely to be large, the additional costs of the proxy contest will not be bid-discouraging and the agency costs we have discussed will occur. When synergies are likely to be small relative to the cost of acquiring the firm by means of a proxy contest, the agency problem is eliminated and the outcome is the same as in management discretion. 
Which of these outcomes is most likely? Since our discussion is model-specific, we cannot draw general conclusions. In particular, our discussion does not factor in the informational effect of a proxy contest versus a tender offer. Critical to the effective workings of the legal regime is that when shareholders get the right to decide the outcome, that they be informed as possible. The disclosure rich environment of the takeover battles is the bulwark of the shareholder choice model. It is very possible that a proxy contest adds valuable information that makes mistakes less likely. If this is the case, although a layered process of a hostile tender offer followed by a proxy contest may be the most efficient rule.

\section{Market Efficiency and Alternative Justifications for Management Discretion}

An important contribution of this paper is to deal explicitly with the interaction between financial market efficiency and the appropriate legal regime for governing takeover defenses. Indeed, assumptions about market efficiency are closely related to the informational issues that we discuss in section 2, and have to be the cornerstone assumptions for any rigorous analysis of the efficiency of alternative legal regimes. Ultimately, the value of giving managers discretion to make decisions on the optimal corporate policy is that they are better informed than shareholders. While it is widely agreed that the costs of non-delegation require that the managers conduct the day-to-day affairs of the company, longer-range corporate policy issues could decided by shareholder if managers were not better informed. Hence, if financial markets become strong-form efficient in the disclosure-rich environment of a takeover battle, shareholders know as much about the value of the firm as do managers and shareholder choice would appear to be the winning argument.

In fact, the relationship between market efficiency and the appropriate legal rule for regulating defensive strategies in takeover battles is complex. Among the first claims for management discretion was the arguments advanced by Martin Lipton and his associates (Lipton and Rowe, 2002). Their argument was that financial markets were inefficient even in the midst of a takeover battle. Consequently, companies that were under-priced could be taken over in a hostile bid absent a management discretion legal regime. Wachter has shown that, in fact, the claim that financial markets are inefficient, perhaps paradoxically, does not favor management discretion at all. The problem with the Lipton argument is that if the market is inefficient enough, the target's shares may remain under-priced for a very long time, so the shareholders should be able to cash out at any bid above market price even if that price is below going concern value. Indeed, going-private transactions are efficiency enhancing in such a world, since such transactions or the threat of such transactions brings transaction prices closer to going concern value.

The key part of the Wachter argument, which we build on in our earlier paper, is that managers may respond to the threat of takeovers by managing to the market. This is an agency cost to the extent that managers are better informed than shareholders, but ignore their own information to do what the shareholders prefer. The market never 
discovers the mismanagement because it occurs under the protection of the business judgment rule when the managers fail to make a positive NPV investment that the market dislikes. ${ }^{19}$ Because the market believes that the managers have made the correct decision it rewards the managers with a high share price rather than penalizing the mismanagement. The increase in the share price protects managers from the risk of being taken over and it is the desire to reduce this risk by raising the share price that motivates managers to acquiesce to the market. Even if the shareholders were ultimately able to discover that the managers knew they had made the wrong the decision, they would be unlikely to punish managers for making a decision that was preferred by the investors.

The agency problem described in this paper also arises when managers fail to make an investment that they know should be made. Since there is no subsequent investment performance on which to base a judgment about the wisdom of the managers' decision, the market simply never learns whether the managers destroyed value or not. Furthermore, the decision not to invest is made under the protection of the business judgment rule and investors lack the legal tools that might enable them to investigate the wisdom of the managers' decision. Because there is no reason to believe that markets can learn that an investment not made should have been, the agency problem we describe cannot be solved by contracting. For the same reason markets are unable to punish managers who fail to make good investments because of the agency problem. Specifically, the absence of experience makes it impossible for markets to bid down the firm's share price as a way of penalizing managers who fail to make good investments.

In our earlier work and in this paper, we recognize that the financial markets will ultimately learn what mangers know about investments that are made and the markets will be strong form efficient. Thus, if our agency problem had resulted in inefficient investments, the market could penalize the managers by bidding down the price of the shares, not only reflecting the value destruction of the managers' decision, but also reflecting the possibility that managers may make such poor choices again. In such a circumstance any desired entrenchment effect would be lost, and the managers' income would fall because of the decline in the value of the stock. Shareholders who learn that managers have made inefficient investments can, of course, impose even more severe punishments by reducing the managers' compensation or replacing them. The threat of these penalties works like implicit contracts and could eliminate the agency problem in cases where bad investments are actually being made.

A paper by Arlen and Talley (2003) presents an argument that is similar to those of the present paper and of our earlier papers. The agency problem they describe is very similar to the one described here and in our earlier paper. It results in inefficient investment decisions protected by the business judgment rule and the inefficient decisions are motivated by management's desire to prevent hostile bids. In contrast to the agency problem of the present paper the Arlen-Talley agency problem involves observable overinvestment in assets that can be used as part of a strategy to deter takeovers. In particular, managers over-invest in assets that can subsequently be sold contingent on the occurrence of an acquisition. These transaction-based business strategies are defensive measures that work very much like a poison pill. ${ }^{20}$ In the Arlen 
and Talley model, managers have no informational advantage over outside investors who are aware that managers are making inefficient investments. The fact that managers have destroyed firm value by choosing to make the wrong investment so as to discourage a hostile bid becomes known to the market and reduces the firm's value.

Although the market is aware of the value destruction, Arlen and Talley assume that the investment decision is "not contractible" and therefore cannot be punished. In other words, the financial market knows that the managers have reduced firm value, but is unable to take action to prevent it or to redress it after the fact. Since the managers know that they will never be held to account for their misdeeds they are free to make them and are thus able to effectively entrench themselves.

The idea that shareholders cannot perfectly contract with managers to enforce good behavior is a reasonable assumption, but the idea of perfect non-contractability seems implausible if that term is taken to mean that shareholders cannot punish observable bad behavior. As long as the bad behavior becomes known, shareholders will be inclined to assume that managers who have behaved badly once will do so again. This should lead to a decline in the share price that makes the firm more susceptible to a takeover. Such a response to observed bad behavior is likely to occur even in the case of dispersed shareholders who are rationally apathetic and therefore do not invest their time and money in forcing managers to act in the interest of shareholders. As long as the bad behavior become known, managers are likely to be punished for bad behavior in the form of a lower stock price.

Perfect non-contractibility is even more unlikely in the case of markets that are strong-form efficient. When markets are efficient in this sense, investors learn soon after an investment has been made whether it should have been. In such a situation, there is every reason for managers to expect to be punished for making bad investments. Thus, when markets are strong form efficient, implicit contracts should provide managers with the same incentives they would face if explicit contracts were in place. When investment performance is observable, these implicit contracts can be implemented without any costly information acquisition by investors and can arise even if shareholdings are dispersed.

However, as institutional investors emerge, such as private equity and hedge fund investors, investment in learning about even nonpublic information is more likely. Such institutional investors, having invested in information gathering to guide their informed investment decisions, are particularly unlikely to allow managerial bad decisions to go unpunished. In other words, as markets become more efficient, active investors are likely to replace inactive ones and bad deeds are even more likely to be punished. The key point is that managers cannot expect to go unpunished if they are observed to have destroyed shareholder value by making bad investments that enable them to adopt defensive techniques.

Known bad behavior is simply not part of an effective takeover defense. The protection of the business judgment rule is needed, not only to protect the decision from 
being contested - as in the Arlen and Talley paper-but also to protect the facts behind the decision from becoming known. In our model, the specific problem just discussed is avoided because under our assumptions the financial market never learns when managers make bad decisions.

\section{Conclusion}

In closing, we return to the starting point. Is there a conceptual framework that supports a rule of management discretion and is this framework consistent with the Delaware's courts basic tenets? We believe that the answer is yes with our model providing the basic framework. This is surely not to claim, however, that the Delaware courts have any such deductive model explicitly in mind. Nor does it claim to reconcile the inconsistencies apparent in the case law. Instead, we have built on what we take to be Delaware's corporate law's two core concepts.

Delaware corporate law has two continuing themes that we have used to form our model. First, corporate managers are best suited to decide on the firm's corporate policy because they are better informed than the market as to the investment opportunities available to the firm. ${ }^{21}$ Second, the legal rule has to be one that best encourages managers to act as faithful fiduciaries. The teachings of Unocal with respect to takeover defenses and the case law that followed it are based on just such an assumption. The judges are quite aware that managers can sometimes operate to further their own interest rather than the interests of the corporation. What legal rule for takeover defenses makes this bad play least likely to occur? ${ }^{22}$

The traditional claim is that shareholder choice provides the best incentives for managers to act faithfully because they are subject to the discipline of efficient capital markets. We challenge that conclusion by identifying a new type of agency cost that occurs in a shareholder choice context but not when the legal rule is management discretion. The agency cost occurs because managers can choose among corporate policies in a manner that is undetected by the market because it occurs behind the barriers of the business judgment rule. In a management discretion regime, but not in a shareholder regime, the managers have the incentive to maximize the value of the firm even when making decisions that are protected from shareholder inspection and challenge.

Our model departs from Delaware case law only in assuming strong-form efficiency, which is clearly inconsistent with the courts' mistrust of market prices and the ability of shareholders to become fully informed. ${ }^{23}$ Our purpose in assuming strongform efficiency is only to test whether the court's teachings with respect to takeover defenses would be invalidated were such an assumption warranted. ${ }^{24}$ The answer is that a rule of management discretion is still consistent, even if markets are strong-form efficient as that term is generally understood. Shareholders may be fully informed as to the value of the corporation's assets and policy, but they will still not learn the value of corporate policies that managers have failed to adopt, and this provides the cover for faithless fiduciaries under a shareholder choice regime. 
This paper also provides some new intuition with respect to perhaps the oldest debate on the appropriate legal rule for takeover defenses. The earliest argument for shareholder choice was the Easterbrook and Fischel (1981) model that the legal rule should require managers to be passive when faced with a hostile tender offer. This was effectively countered separately by Bebchuk (1982) and Gilson (1981) who argued that takeover defenses were appropriate because they allowed managers to bargain for and secure a higher price for the shareholders of target companies. But this justification of takeover defenses contains a built in puzzle if one assumes that shareholders are rational investors. Rational investors are fully diversified shareholders and such investors are indifferent as to the premium secured by managers in a hostile tender offer. The reason is that fully diversified shareholders own both the bidder and the target and thus are both payers and payees of the premium. They lose on one stock what they gain on the other. That means that shareholders should only favor legal rules that increase the total value of all the companies in the financial market. The puzzle is avoided if the takeover defenses employed in a management discretion regime do indeed, as we have argued here, increase the total value across firms by eliminating the agency problem posed by a shareholder choice legal regime.

Our analysis can also be used to provide an explanation to a puzzle, raised by Daines and Klausner (2001), with respect to the adoption of takeover defenses by many firms prior to their initial public offering (IPO). They ask why shareholders put up with such tactics in the IPO context? The expectation, with which we agree, is that at the IPO stage shareholders should have the most power and at that stage managers should be most likely to follow shareholders' preferences. If takeover defenses have a negative effect on the value of the firm, why is it that shareholders appear to be indifferent in pricing between corporations that have effective takeover defenses and those that do not? In effect, the market either does not mark down the price of firms that have such provisions, or the markdown is one that managers are willing to absorb. Daines and Klausner work through various possible explanations but do not find one that fits their data.

Our answer is simply that effective takeover defenses may be of value to shareholders. The prediction of our model is that the choice of effective takeover defenses should not obviously have a material affect on the IPO price. At the end of the day, the choice between management discretion and shareholder choice is a tradeoff and thus any price effect of takeover defenses will also reflect this tradeoff. If the tradeoff is close to a "wash," then the expected market price should be zero.

Finally, this paper is complementary with the paper by Kahan and Rock (2003). They point out that the corporation's articles of incorporation express the wishes of the managers and the shareholders and their choices should be respected by the courts. Hence, if the parties choose a staggered board, then that choice of a takeover defense should be respected by the courts. But why should the courts treat deferentially the original choice of the parties? If shareholders are the residual claimants who "own" the company and a majority of shareholders wants to overturn takeover defenses so as to facilitate a hostile bid, why not have the courts' enforce the shareholders choice? Why 
give greater deference to some private allocation of power agreed to by the directors and the shareholders? In other words, why does the board "count" since they are the elected representatives of the shareholders and they can be replaced by a majority vote?

Our answer here parallels our answer to the earlier question. The shareholders want to be able to delegate certain decisions to the board so that the board or managers can rely on it when they carry out their responsibility for establishing and implementing the firm's corporate policy. If managers believe the corporation's certificate and by-laws puts them in a management discretion legal regime then they can make the appropriate corporate policy decisions without having to factor into their calculus the probability of a hostile tender offer. Should the applicable legal rule be alterable without management agreement, then rational managers will assume they are governed by shareholder choice and make their corporate policy decisions accordingly.

In summary, we conclude that the classic dilemma of corporate policy remains intact: although managers will act in their own interests, shareholders need to delegate to the managers the ability to choose the corporate policy that maximizes the value of the shareholder's residual share. Even with strong-form efficiency as their term is generally understood, managers can make decisions - in particular, can avoid policies that make hostile bids more likely - that are not discoverable because of the protection of the business judgment rule. Depending upon the tradeoffs identified in our modelshareholders may at the end of the day be better served by a legal regime of management discretion than shareholder choice.

\footnotetext{
${ }^{\dagger}$ The authors are respectively, the Miller Friedman Professor of Finance, Wharton School and the William B. Johnson Professor of Law and Economics and Co-Director of the Institute for Law and Economics. This paper has benefited from comments made at presentations to the NYU/Penn Conference on Law and Finance, the Wharton Finance Seminar Series, the Summer Finance Conference at the University of British Columbia, and a Department Seminar at Pompeu Fabra in Barcelona. Special thanks to Edward Rock, Steve Ross, Krishna Ramaswamy, Nicolae Garleanu, and Esben Eckbo for comments on an earlier draft and to Bonnie Clause for editorial assistance.

${ }^{1}$ This paper builds on Kihlstrom and Wachter (2003). See also Wachter (2003).

${ }^{2}$ We use the term management discretion to refer to the Delaware legal regime that can be interpreted as permitting managers to maintain takeover defenses in place in the face of a hostile tender offer as long as those defenses are neither coercive nor preclusive. The legal rule for Delaware corporations is developed in Unocal Corp. v. Mesa Petroleum Co. and Unitrin, Inc. v. American General Corp. See, also, Veasey (1997).

${ }^{3}$ By shareholder choice we mean a legal regime that would prevent managers from maintaining takeover defenses beyond a period of time that would allow them to offer an alternative to the takeover bid. The shareholder choice model was first developed in the early 1980s. (Gilson, 1981; Easterbrook and Fischel, 1981; Bebchuk, 1982). Later articles taking this position include: Coffee, Jr., (1997); Gordon, (1997); Bebchuk (2002); Bebchuk et al. (2003). The shareholder choice position can, for expositional purposes, be identified with the Chancery Court's holding in City Capital Ass'n v. Interco, Inc.. According to Interco's reasoning, target management could use its poison pill to hold off the immediate clutches of an unwanted suitor. But the firm would eventually have to be sold, possibly to the existing management team should they mount a management buy-out ("MBO"), unless the shareholders could be quickly convinced to value the current earnings prospects of the firm more highly.

${ }^{4}$ Gilson states "The statute, like a golem, requires an animating principle to come alive. ...But Unitrin's effective abandonment of Unocal's regulatory function brings us back to the need for an animating justification: why should the court prefer elections to markets?”
} 
${ }^{5}$ Others who have written in favor of management discretion include Lipton and Rowe (2002), Blair and Stout (1999); Lynn A. Stout (2002); and Bainbridge (2003). In his original writings, Lipton (1979) advocated applying the business judgment rule to decisions involving hostile tender offers.

${ }^{6}$ We follow the conventional definitions of strong and semi-strong-form efficiency (Campbell et al., 1997; Brealey, Myers, and Allen 2006).

${ }^{7}$ Deviations from strong-form efficiency undercut the rational for the efficiency of a shareholder choice legal regime. In our model, market efficiency is needed to secure the main benefit of shareholder choice; namely using the market for control as a device to discipline managers by reducing their private benefits and by encouraging them to adopt value-enhancing corporate policies. If markets become strong-form efficient in the context of a takeover battle, then all transactions are value enhancing to shareholders. If this is not the case and managers have superior information to the market, then the firms that are taken are not those that have high agency costs, but instead are those that are inefficiently priced. In this case, the threat of takeovers does not encourage managers to minimize their private benefits, rather the threat encourages them to manage to the financial markets, even when their own superior information suggests an alternative policy.

${ }^{8} \S 141$ (a) states that "The business and affairs of every corporation ... shall be managed by or under the direction of a board of directors” Delaware General Corporation Law. Under Delaware case law, the business judgment rule is ... a presumption that in making a business decision, the directors of a corporation acted on an informed basis; in good faith and in the honest belief that the action taken was in the best interests of the company. Absent an abuse of discretion, that judgment will be respected by the courts. The burden is on the party challenging the decision to establish facts rebutting the presumption." Aronson v. Lewis, 473 A.2d 805 (Del. 1984).

${ }^{9}$ The resolution to the classical dilemma is a settled matter of law in the case of ordinary business judgments. In such cases the business judgment rule provides a highly deferential rule that gives directors extensive authority to decide on corporate policies without challenge from disgruntled shareholders. Few commentators disagree, and would assign greater discretion to shareholders to choose the appropriate corporate policy. The dilemma is far from being resolved appropriately in the case where a hostile bidder appears who is willing to buy the shares of the corporation above the existing market price. If the bid succeeds, the directors lose their jobs and private benefits.

${ }^{10}$ This point was suggested by Stephen Ross in a seminar where our paper was presented.

${ }^{11}$ Our model does not have a specific "takeover" period so that we cannot focus on this assumption rather than the more general assumption that strong-form efficiency always holds.

${ }^{12}$ As discussed below, we define private benefits as the component of managers' compensation that is above the opportunity pay of the managers.

13 "In particular, long-term contracts executed under conditions of uncertainty are ones for which complete presentation is apt to be prohibitively costly if not impossible. Problems of several kinds arise. First, not all future contingencies for which adaptations are required can be anticipated at the outset.” (Williamson, 1979).

${ }^{14}$ Kihlstrom and Wachter (2003). In this, we follow Hart (1989) who views the firm as a set of property rights including asset ownership and residual control rights. See, also Rock and Wachter (2001).

${ }^{15}$ Strictly speaking, the managers' compensation includes their opportunity wage, and this component may be part of $\mathbf{b}$ and/or part of $\mathbf{s}$. For simplicity, however, we will assume that $\mathbf{b}$ does not include an opportunity wage component.

${ }^{16}$ In Kihlstrom and Wachter (2003), we addressed the case where managers actually make investments in policy options that are out-of-the-money in a PV sense because making the investment reduced the probability of a takeover. We could have allowed for this possibility in this paper, but there is no loss in generality by omitting that possibility in the current model.

${ }^{17}$ In saying this we are not taking a position as to whether poison pills are, on balance, positive or negative with respect to shareholders wealth. Our only point is that the gains to shareholders in a potentially higher price in a takeover will be offset to some extent by an increase in the private benefits that managers will be able to extract if they are maximizing their own compensation.

${ }^{18}$ This topic was first addressed in the important paper by Gilson and Schwartz (2001).

${ }^{19}$ In industries with several firms that produce homogeneous products that are sold in the same product market, shareholders may learn of missed investment opportunities by analyzing the investment choices of 
the other firms in the industry. Hence, the appeal of our argument is likely to vary among industries. We do not analyze the industry-specific issue in this paper.

${ }^{20}$ In the Arlen and Talley (2003) model, managers decide whether to continue with their current strategy or to switch to an alterative strategy that involves investing in an asset that must be sold if a takeover occurs. The alternative investment is sometimes more valuable than the firm's current operations and sometimes less valuable. The manager decides whether to make the investment knowing if the new investment is more or less valuable than the firm's current operations. Under management discretion the manager always make the investment decision preferred by shareholders, but under shareholder choice the manager sometimes chooses to make the investment when the shareholders prefer the continuation of current operations. The manager misbehaves in this way because he desires the protection from a hostile bid provided by the fact that the asset has to be sold when a takeover takes place.

${ }^{21}$ Case law has continually emphasized the foundational role of $\S 141$ that gives the directors and their appointed managers the power and responsibility for conducting the business and affairs of the corporation. The directors' fiduciary duties are a "constant compass," and any abdication of those responsibilities is rejected. This provides the foundation for a host of court ruling including the restrictions on dead-hand poison pills to the perceived delegation of the right to sale the company to a controlling shareholder or CEO. For example, in Carmody v. Toll Brothers, Inc., then Vice Chancellor Jack Jacobs concluded that a deadhand poison pill interferes with the director's statutory power to manage the business and affairs of the corporation. Carmody v. Toll Brothers, Inc., 723 A.2d 1190 (Del Ch. 1998). The Delaware Supreme Court, stating that directors have an "unremitting obligation" to meet their statutory obligations under 141(a) struck down a "delayed redemption provision" as being in violation of fundamental principles of Delaware law. Quickturn Design Systems Inc. v. Shapiro, 721 A.2d 1281 (Del. 1998).

${ }^{22}$ One commentator has said that our defense of management discretion is akin to justifying a "protection racket," in that we are giving managers more power to deter them from doing something really harmful otherwise. But the analogy does not work. Under management discretion, managers are not being paid off and only gain to the extent they maximize the value of the firm. The problem only arises under shareholder choice. Favoring management discretion thus follows the traditional principle of favoring the legal rule that best aligns the interests of director/managers and shareholders.

${ }^{23}$ In Smith v. Van Gorkom, the Delaware Supreme Court explicitly distinguished between the intrinsic value of a corporation and its market value as determined in a financial market. Smith v. Van Gorkom, 488 A.2d 858 (Del. 1985). Van Gorkom, the CEO of TransUnion, offered to sell the company to Jay Pritsker, a leveraged buyout specialist, for $\$ 55$ per share. The stock had been trading between the low 20s and upper 30s. The Delaware Supreme Court concluded that the board of directors was inadequately informed when they approved the agreement, and they should have actively solicited alternative bids once they decided to sell the company. In the appraisal law context, the courts have limited the role that market prices can apply in determining the fair value of a company.

${ }^{24}$ Our early papers are more consistent with the case law in assuming that managers may have better ongoing information as to the true value of the firm than do the shareholders. Wachter (2003) and Kihlstrom and Wachter (2003) 


\section{References}

Arlen, Jennifer, and Eric Talley. 2003. "Unregulable Defenses and the Perils of Shareholder Choice,” 152 University of Pennsylvania Law Review 577.

Aronson v. Lewis, 473 A.2d 805 (Del. 1984).

Bainbridge, Stephen M. 2003. "Director Primary: The Means and Ends of Corporate Governance,” 97 Northwestern University Law Review 547.

Bebchuk, Lucian Arye et al. 2003. "The Powerful Antitakeover Force of Staggered Boards: Further Findings and a Reply to Symposium Participants,” 55 Stanford Law Review 885.

Bebchuk, Lucian Arye. 2002. “The Case Against Board Veto in Corporate Takeovers,” 69 University of Chicago Law Review 973.

---. 1982. “The Case for Facilitating Competing Tender Offers,” 95 Harvard Law Review 1028.

Blair, Margaret M. and Lynn Stout. 1999. “A Team Production Theory of Corporate Law,” 85 Virginia Law Review 247.

Brealey, Richard A., Stewart C. Myers and Franklin Allen. 2006. Principles of Corporate Finance. McGraw-Hill.

Campbell, John Y., Andrew W. Lo and A. Craig MacKinlay. 1997. The Econometrics of Financial Markets. Princeton Univ. Press.

Carmody v. Toll Brothers, Inc., 723 A.2d 1190 (Del Ch. 1998).

City Capital Ass’n v. Interco, Inc., 551 A.2d 787, 802 (Del. Ch. 1988).

Coffee, Jr., John C. 1997. "The Bylaw Battlefield: Can Institutions Change the Outcome of Corporate Control Contests,” 51 University of Miami Law Review 605.

Daines, Robert and Michael Klausner. 2001. "Do IPO Charters Maximize Firm Value? Antitakeover Protection in IPOs,” 17 Journal of Law, Economics and Organization 83.

Easterbrook, Frank H. and Daniel R. Fischel. 1981. “The Proper Role of a Target's Management in Responding to a Tender Offer,” 94 Harvard Law Review 1161.

Gilson, Ronald J. 1981. “A Structural Approach to Corporations: The Case Against Defensive Tactics in Tender Offers,” 33 Stanford Law Review 819. 
---. 2001. "Unocal Fifteen Years Later (And What We Can Do About It)," 26 Delaware Journal of Corporate Law 491.

Gilson, Ronald J. and Alan Schwartz, 2001 "Sales and Elections as Methods for Transferring Corporate Control,” 2 Theoretical Inquiries in Law.

Gordon, Jeffrey. “'Just Say Never?’ Poison Pills, Deadhand Pills and Shareholder Adopted Bylaws: An Essay for Warren Buffett,” 19 Cardozo Law Review 511.

Grossman, Sanford, and Oliver Hart. 1986. "The Costs and Benefits of Ownership: A Theory of Vertical and Lateral Integration,” 94 Political Economy, 691.

Hart, Oliver. 1989. "An Economist’s Perspective on the Theory of the Firm,” 89 Columbia Law Review 1757.

Kahan, Marcel, and Edward B. Rock. 2003. "Corporate Constitutionalism: Antitakeover Charter Provisions as Precommitment,” 152 University of Pennsylvania Law Review 473.

Kihlstrom, Richard E., and Michael L. Wachter. 2003. "Corporate Policy and the Coherence of Delaware Takeover Law," 152 University of Pennsylvania Law Review 523.

Lipton, Martin 1979. “Takeover Bids in the Target’s Boardroom,” 35 Business Law 101.

Lipton, Martin, and Paul K. Rowe. 2002. "Pills, Polls and Professors: A Reply to Professor Gilson," 27 Delaware Journal of Corporate Law 1.

Paramount Communications, Inc. v. Time, Inc., 571 A.2d 1140, 1152 (Del. 1989).

Quickturn Design Systems Inc. v. Shapiro, 721 A.2d 1281 (Del. 1998).

Revlon, Inc. v. MacAndrews \& Forbes Holdings, Inc., 506 A.2d 173 (Del. 1986).

Rock, Edward B. and Michael L. Wachter. 2001. Islands of Conscious Power: Law, Norms, and the Self-Governing Corporation, 149 University Pennsylvania Law Review 1619.

Smith v. Van Gorkom, 488 A.2d 858 (Del. 1985).

Stout, Lynn A. 2002. "Bad and Not-So-Bad Arguments for Shareholder Primacy,” 75 Southern California Law Review 1189.

Unitrin Inc. v. American General Corp., 651 A.2d 1361, 1367 (Del. 1995).

Unocal Corp. v. Mesa Petroleum Co., 493 A.2d 946 (Del. 1985). 
Veasey, E. Norman. 1997. "The Defining Tension in Corporate Governance in America,” 52 Business Law 393.

Wachter, Michael L. 2003. “Takeover Defense when Financial Markets Are (Only) Relatively Efficient,” 151 University of Pennsylvania Law Review 787.

Williamson, Oliver. 1979. "Transaction Cost Economics: The Governance of Contractual Relations,” 22 Journal of Law and Economics 233, 237. 